\title{
PRELIMINARY ANALYSIS OF CORE TEMPERATURE DISTRIBUTION OF EXPERIMENTAL POWER REACTOR USING RELAP5
}

\author{
Andi Sofrany Ekariansyah ${ }^{1 *}$, Surip Widodo ${ }^{1}$, Hendro Tjahjono ${ }^{1}$, Susyadi ${ }^{1}$, \\ Puradwi I. Wahyono ${ }^{2}$, Anwar Budianto ${ }^{3}$ \\ ${ }^{1}$ Center for Nuclear Reactor Technology and Safety, Puspiptek Area, Setu, Tangerang Selatan, 15310 \\ ${ }^{2}$ Center for Science and Accelerator Technology, Jl. Babarsari, Kotak Pos 6101YKBB, Yogyakarta \\ ${ }^{3}$ Polytechnic Institute of Nuclear Technology, Jl. Babarsari, Kotak Pos 6101YKBB, Yogyakarta \\ "E-mail: andi_se@batan.go.id \\ Diterima editor: 10 Oktober 2018 \\ Diperbaiki: 30 Oktober 2018 \\ Disetujui untuk publikasi: 31 Oktober 2018
}

\begin{abstract}
PRELIMINARY ANALYSIS OF CORE TEMPERATURE DISTRIBUTION OF EXPERIMENTAL POWER REACTOR USING RELAP5. High Temperature Gas Cooled Reactor (HTGR) is a high temperature reactor type having nuclear fuels formed by small particles containing uranium in the core. One of HTGR designs is Pebble Bed Reactor (PBR), which utilizes helium gas flowing between pebble fuels in the core. The PBR is also the similar reactor being developed by Indonesia National Nuclear Energy Agency (BATAN) under the name of the Reaktor Daya Eksperimental (RDE) or Experimental Power Reactor (EPR) started in 2015. One important step of the EPR program is the completion of the detail design document of EPR, which should be submitted to the regulatory body at the end of 2018. The purpose of this research is to present preliminary results in the core temperature distribution in the EPR using the RELAP5/SCDAP/Mod3.4 to be complemented in the detail design document. Methodology of the calculation is by modelling the core section of the EPR design according to the determined procedures. The EPR core section consisting of the pebble bed, outlet channels, and hot gas plenum have been modelled to be simulated with $10 \mathrm{MWt}$. It shows that the core temperature distribution under assumed model of 4 core zones is below the limiting pebble temperature of $1,620^{\circ} \mathrm{C}$ with the highest pebble temperature of $1,477.0^{\circ} \mathrm{C}$. The results are still preliminary and requires further researches by considering other factors such as more representative radial and axial power distribution, decrease of core mass flow, and heat loss to the reactor pressure vessel.
\end{abstract}

Keywords: Pebble bed, core temperature, EPR, RELAP5

\section{ABSTRAK}

ANALISIS AWAL DISTRIBUSI TEMPERATUR TERAS REAKTOR DAYA EKSPERIMENTAL MENGGUNAKAN RELAP5. High Temperature Gas Cooled Reactor (HTGR) adalah reaktor tipe temperatur tinggi yang memiliki bahan bakar nukir dalam bentuk bola-bola kecil yang mengandung uranium. Salah satu desain HTGR adalah reaktor pebble bed (Pebble bed reactor/PBR) yang memanfaatkan gas helium sebagai pendingin yang mengalir di celah-celah bahan bakar bola di dalam teras. PBR juga merupakan tipe reaktor yang sedang dikembangkan oleh BATAN dengan nama reaktor daya eksperimental (RDE) yang dimulai pada 2015. Salah satu tahapan penting dalam program RDE adalah penyelesaian dokumen desain rinci yang harus dikirimkan ke badan pengawas pada akhir 2018. Tujuan penelitian adalah untuk menyajikan hasil-hasil awal pada distribusi temperatur di teras RDE menggunakan RELAP5/SCDAP/Mod3.4 sehingga dapat melengkapi isi dokumen desain rinci. Metode perhitungan adalah dengan memodelkan bagian teras RDE sesuai hasil penelitian sebelumnya. Bagian teras RDE yang dimodelkan terdiri dari pebble bed, kanal luaran, dan plenum gas bawah yang disimulasikan pada daya $10 \mathrm{MWt}$. Hasil simulasi menunjukkan bahwa distribusi temperatur teras dengan asumsi pembagian 4 zona teras mendapatkan temperatur tertinggi sebesar $1477{ }^{\circ} \mathrm{C}$ yang masih di bawah batasan temperatur di bola bahan bakar yaitu $1620{ }^{\circ} \mathrm{C}$. Hasil yang diperoleh masih estimasi awal dan membutuhkan penelitian lebih lanjut dengan mempertimbangkan faktor-faktor lainnya seperti distribusi daya aksial dan radian yang lebih representatif, pengurangan aliran teras, dan kehilangan panas teras yang diserap oleh bejana reaktor.

Kata kunci: Pebble bed, temperatur teras, RDE, RELAP5

DOI: $10.17146 / \mathrm{tdm} .2018 .20 .3 .4665$ 


\section{INTRODUCTION}

High Temperature Gas Cooled Reactor (HTGR) is a high temperature reactor type having nuclear fuels formed by small particles containing uranium in the core. There are two HTGR types looking at the core design, which are prismatic core HTGR, also defined as Prismatic Modular Reactor (PMR), and pebble bed core HTGR or Pebble Bed Reactor (PBMR) [1, 2]. Both HTGR designs utilize the helium gas, which flows as a coolant to remove generated heat in the core. Pebble bed reactors are considered as the most advanced technology especially to power the future hydrogen economy by offering the advantages of emission free operation, high energy efficiency, and naturally safe or physically no fuel meltdown is possible [3]. The PBR also drew attention in Indonesia to be part of the one of national program to support the National Medium Term Development Plant in year 2015 - 2019 by starting the Reaktor Daya Eksperimental (RDE) or Experimental Power Reactor (EPR) program in 2015, conducted by the Indonesia National Nuclear Energy Agency (BATAN). The main goal of EPR program is to develop national capability of BATAN in the nuclear reactor technology by mastering the design, construction project management, commissioning and operation of a experimental power reactor [4]. The EPR program was inspired by the China R\&D program for the HTGR began in the mid-1970s, which accomplished the construction of the HTR-10 test reactor in the 1990s [5]. One important step of the EPR program was the completion of EPR basic engineering design developed internally by BATAN in 2017. The next step of the program is the completion of the detail design document of EPR, which should be submitted to the regulatory body at the end of 2018.

One part of the EPR detail design document is the description related to the core design, which should be confirmed by any calculations. The calculation can be achieved by conducting simulation using proven code to present the required parameters. One particular code owned by BATAN is the RELAP5/SCDAP/Mod3.4, which is originally developed for the thermal hydraulic transient simulation of light water reactor coolant systems. The use of RELAP5 to simulate the PBR, especially in the core, can be found in the thermal modelling of HTR-10 design $[6,7]$. The purpose of this research is to present preliminary results in the core temperature distribution in the EPR using the RELAP5/SCDAP/Mod3.4 to confirm its design parameter with the EPR basic design. Methodology of the calculation is by modelling the core section of the EPR design according to the procedure summarized in the previous research [8]. The research has described the methodology of modelling pebble and void gaps inside pebbles using RELAP5, which is full adopted in this research. Parameters to be calculated are core inlet and outlet temperature and core temperature distribution measured in the pebbles in the various positions in the EPR core. The results of the calculation, in particular the core temperature distribution, can contribute to the EPR reactor modelling to obtain a representative model of the EPR primary system. As a source of core modelling, the EPR basic design document provided by BATAN [9] as also reference related to the HTR-10 design [10 ] were used.

\section{DESCRIPTION OF THE EPR CORE DESIGN}

By design, the EPR core consists of pebbles stacked together to form a pebble bed inside a round-formed graphit reflector. In total, there are around 27,000 pebbles to generate $10 \mathrm{MWt}$, which is absorbed by the helium gas flowing among pebble gaps. Those pebbles form an active core diameter of $1.8 \mathrm{~m}$ and active core height of $1.98 \mathrm{~m}$. Above the pebbles inside the core, there is an empty space with the height of $0.4 \mathrm{~m}$, in which the helium gas accumulated from the top before entering the pebbles. The pebble or spherical fuel element is a sphere with a diameter of $60 \mathrm{~mm}$ consisting of the inner zone and outer zone. The inner zone has a diameter of $50 \mathrm{~mm}$ containing spherical $\mathrm{UO}_{2}$ kernels with $0.5 \mathrm{~mm}$ diameter and $17 \%$ uranium content, which is surrounded by several pyrolytically deposited layers of carbon and one layer of silicon carbide (SiC). These fuel kernels are uniformly distributed in a carbon matrix to be surrounded by the outer zone shell of the same material as the matrix with approximately $5 \mathrm{~mm}$ thickness. 
The pebble bed is housed by the core bottom, side and top reflector made of graphite. The shape of the inner side reflector wall and the $30^{\circ}$-angled core bottom allow an uniform fuel element flow in to the fuel discharge tube. The helium gas entering the pebble bed will remove the heat generated in the core from the top to the bottom, in which one part of the helium gas will flow inside the outlet channels and the other part in to the fuel discharge tube with a $50 \mathrm{~cm}$ diameter. The helium gas entering the outlet channels in the bottom of the core will be collected in the hot gas plenum before directed to the hot gas duct. Figure 1 illustrates the core design of the EPR showing the placement of the pebble bed, core outlet channels and the hot gas plenum as described in the EPR basic design document [9].

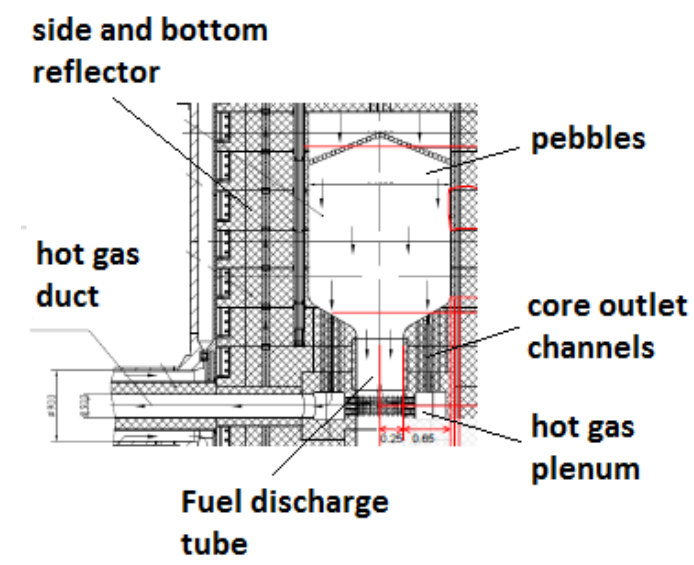

Figure 1. EPR core design showing the position of the reflector, pebble bed, outlet channels, and fuel discharge tube [9]

The figure also illustrates the pattern of the core outlet channels, which are not yet determined related to the EPR basic design. By studying the HTR-10 core design [10], the core outlet channels are assumed to be 640 holes with a $16 \mathrm{~mm}$ diameter each, which will be proposed in the EPR detailed design. The hot gas plenum is made by the bottom graphite reflector with a donut shape having equivalent outer diameter of $166 \mathrm{~cm}$, inner diameter of $112 \mathrm{~cm}$ and the height of $25 \mathrm{~cm}$. Those geometrical data will be utilized in the core modelling using the RELAP5 showing the helium gas flow from the top of the core to the hot gas duct.

\section{RELAP5 MODELING OF EPR CORE}

The first part to be modelled is the core or the pebble bed itself consisting of the helium gas flow inside the pebbles and the heat generation from the pebbles. Therefore it is assumed that the core is divided into 4 radial zones, which are the middle zone, the second, third, and fourth zone. The middle zone has a core diameter similar to the fuel discharge tube, whereas the second to the fourth zones represents core rings with increased outer diameter. To model the helium gas flow inside the pebbles, one parameter to be determined is the average porosity of the pebbles, $\varepsilon_{\mathrm{b}}$, which is estimated by following equation [11]:

$$
\varepsilon_{b}=\frac{0.78}{\left(D / d_{p}\right)^{2}}+0.375
$$

$\varepsilon_{b}$ or the void fraction is defined as the average volume of the gaps between the pebbles in a single volume of the bed. $D$ is the bed diameter according to the core zone and $d_{p}$ is the pebble diameter, which in this case is $60 \mathrm{~mm}$. By knowing the bed volume, void fraction for each pebble diameter, and the bed height, the void flow area can be calculated. Other parameter to be determined are the radial and axial power peaking factor, which represent the heat power distribution in the core radial 
and axial direction. These factor will be used in defining the power factor distribution of the pebbles, which generate heat in the core, as the heat structure components in the RELAP5. For that purpose, data from the EPR basic design document are used representing the power distribution in the OTTO (once through then out) refueling scheme, in which each pebble only passes the core once [12]. Figure 2 shows the scheme of the RELAP5 nodalization in the core zones, fuel discharge tube, outlet channels, and the hot gas plenum.
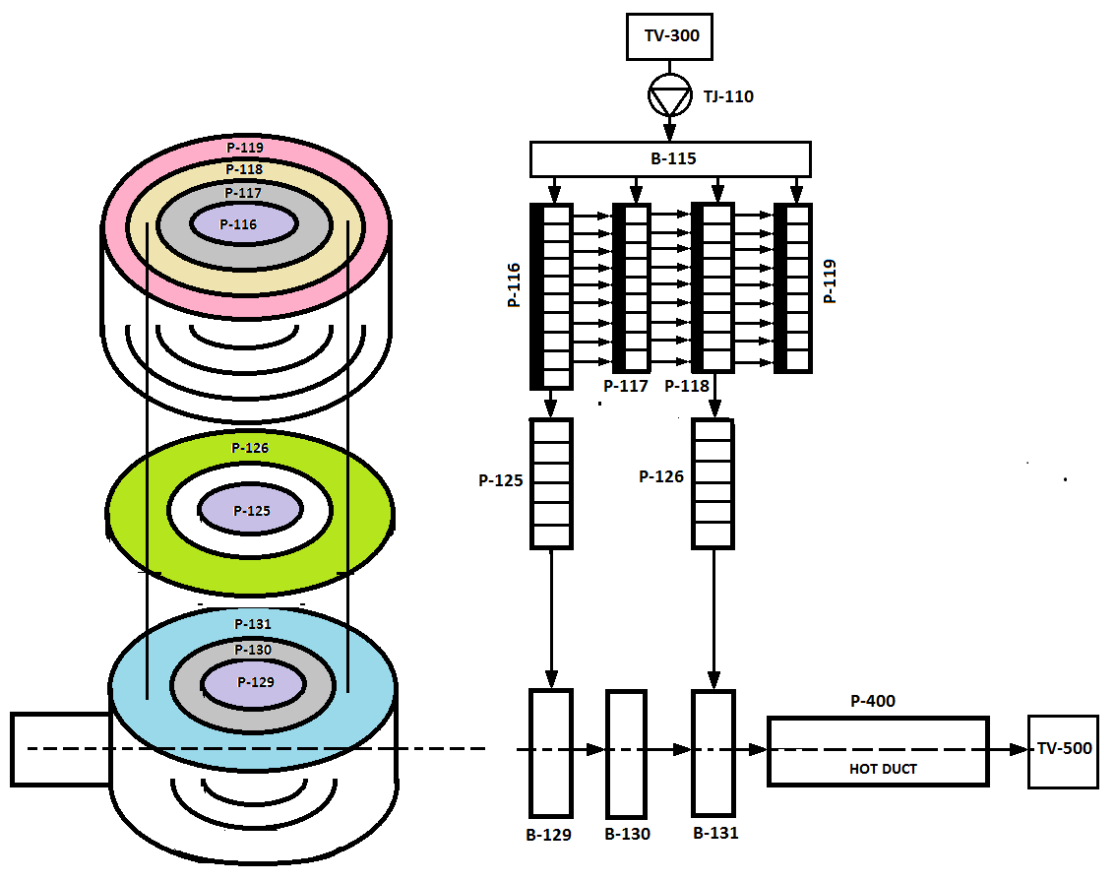

Figure 2. RELAP5 nodalization for the core, outlet channels, and hot gas plenum section.

In the Figure 2, the core model has 2 boundaries represented by the Time-dependent volume of TV-300 for the inlet gas volume and TV-500 for the outlet gas volume. From the inlet gas volume, the helium gas flow is forced by a pump component of Time-dependent junction (TJ-110) to enter the core empty volume of Branch component (B-115) which distributes the helium flow into 4 pebble bed zones. The 4 pebble bed zones are modelled as Pipe components, which are the $\mathrm{P}-116, \mathrm{P}-117, \mathrm{P}-118$, and $\mathrm{P}-119$, which are divided into 10 segments for the P-116 and 9 segments for the rest of the core zones respectively. Each core zone is connected radially to accomodate the cross flow. The P-116 core zone represents the middle core connected directly with the fuel discharge tube of P-125, whereas the P-118 is connected to the helium outlet channels of P-126. Both components are then connected to the B-129, B-130, B-131 as the hot gas plenum before directing the hot helium gas to the hot gas duct of P-400. The core model is then simulated using the RELAP5 by setting the boundary conditions of the helium gas flow rate of $4.27 \mathrm{~kg} / \mathrm{sec}$, core pressure of $3.42 \mathrm{MPa}$, helium inlet temperature of $243{ }^{\circ} \mathrm{C}$ and core power of $10 \mathrm{MWt}$.

\section{RESULTS AND DISCUSSION}

\section{Calculation of the pebbles and void fractions}

The core model represented by the 4 core zones contains parametric values of helium flow area and the number of pebbles to generate heat based on determined void fraction. Table 1 summarizes the calculated parametric data of each core zones used in the RELAP5 simulation. 
Table 1 . Summary of parametric values for the core zones.

\begin{tabular}{llllll}
\hline Parameter & \multicolumn{4}{c}{ Core zone } & Total \\
\cline { 2 - 5 } & 1 & 2 & 3 & 4 & \\
\hline Core diameter, $\mathrm{m}$ & 0.5 & 0.7881 & 0.9983 & 1.1714 & \\
Number of segments & 10 & 9 & 9 & 9 & \\
Pebble diameter, $\mathrm{m}$ & 0.06 & 0.06 & 0.06 & 0.06 & \\
Average porosity & 0.386 & 0.379 & 0.378 & 0.377 & \\
Core height, $\mathrm{m}$ & 1.98 & 1.927 & 1.927 & 1.927 & \\
Void flow area, $\mathrm{m}^{2}$ & 0.075 & 0.185 & 0.295 & 0.406 & \\
Pebble fraction & 0.613 & 0.620 & 0.622 & 0.623 & 26989 \\
Number of pebbles & 2108 & 5154 & 8294 & 11433 & \\
\hline
\end{tabular}

Based on the calculation, the total number of the pebbles for generating heat are 26,989 pebbles, which approachs the EPR design of around 27,000 pebbles. Those numbers are calculated from the value of the pebble fraction and the core volume for the each core zone, whereas the pebble fraction is one minus the average porosity. The core height in the $1^{\text {st }}$ core zone $(\mathrm{P}-116)$ is determined to be $1.98 \mathrm{~m}$, which is longer than other core zones to represent the bottom cone shape of the core.

\section{Temperature distribution for the $\mathbf{4}$ core zones}

The simulation of the core model is objected to calculate the pebble temperature distribution measured in the middle of the pebble. The temperature of the one pebble is similar with the other pebbles of the same segment axially but will be different in the same segment radially. Figure 3 shows the estimated core temperature distribution after 10,000 seconds simulation with $10 \mathrm{MWt}$ core power. The steady-state condition is determined by the steady outlet core temperature, which should approach $700{ }^{\circ} \mathrm{C}$ measured in the P-400.

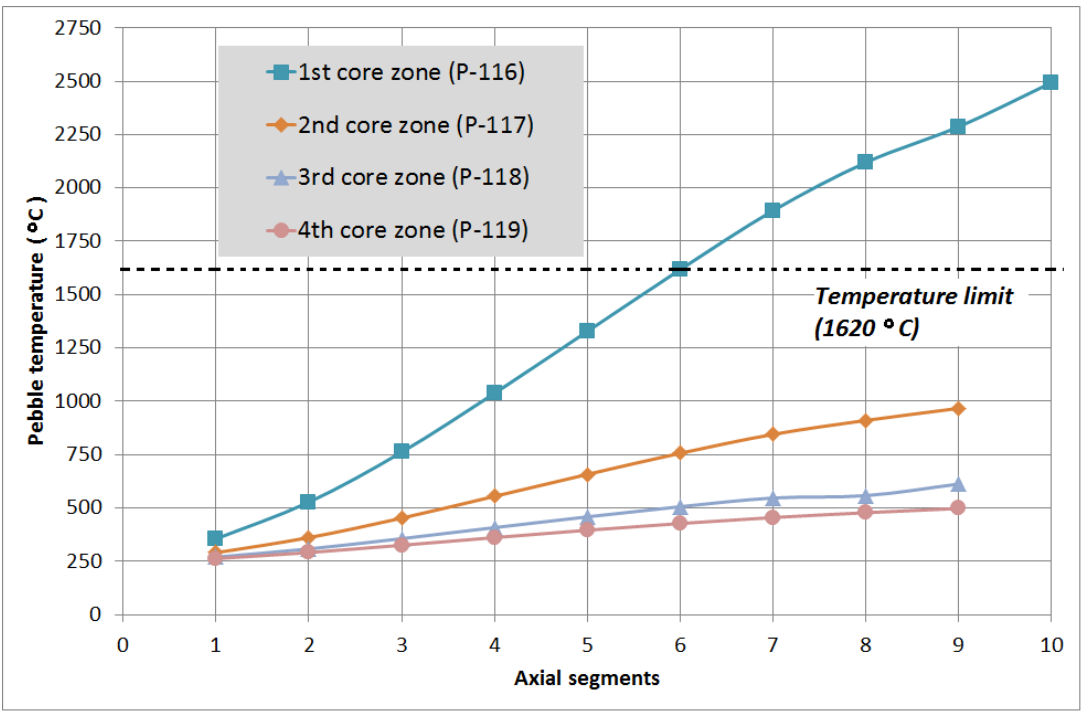

Figure 3. Pebble temperature distribution in the 4 core zones after 10,000 second calculation.

On the Figure 3, the pebble temperature distribution is showed axially from the top of the core $\left(1^{\text {st }}\right.$ segment $)$ to the bottom of the core $\left(10^{\text {th }}\right.$ segment $)$ in the middle core zone or in the $9^{\text {th }}$ segment for the other 3 core zones. The pebble temperature should not exceed the limit temperature in the $\mathrm{SiC}$ layer of $1620^{\circ} \mathrm{C}[4,13,14]$. From the 4 core zones, 3 zones $(\mathrm{P}-117$ to $\mathrm{P}-119)$ show the pebble temperatures below the limit value and the middle core zone (P-116) indicates an anomaly in the temperature distribution exceeding the limit. In the model, the middle core zone is connected directly with the fuel discharge tube before entering the hot gas plenum with high flow resistance. To find the cause of the exceeding the temperature limit, an analysis in the helium gas flow in the pebble void has been conducted in the output data of the RELAP5 and the input data was modified. 
The modification includes the decrease of the flow resistances in the middle core zone. The results of the modification are shown in the Figure 4.

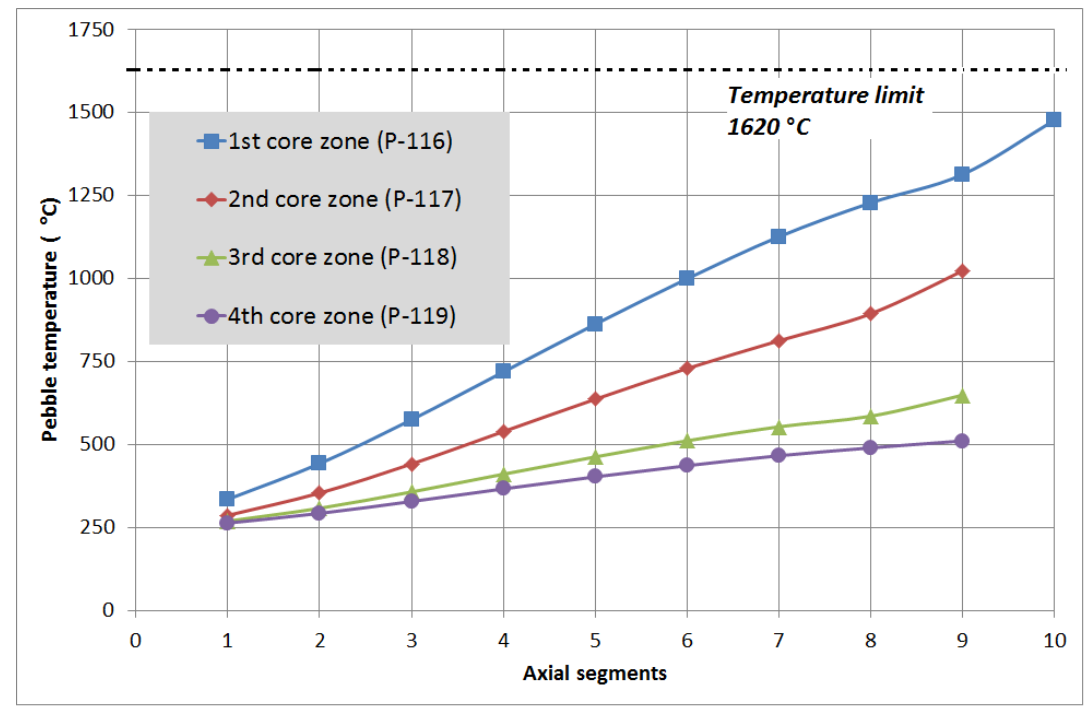

Figure 4. Pebble temperature distribution in the 4 core zones after adjustment in the middle core zone.

In Figure 4, the pebble temperature in the middle core zone is below the limit value as the other core zones. Justification for the adjustment in the flow resistance can be seen in the output data showing the helium mass flow inside the pebbles of the middle core zone, which is almost similar with the $2^{\text {nd }}$ core zone. The pebble temperature measured in the core outlet $\left(10^{\text {th }}\right.$ segment of the middle core zone) has the highest value of $1,477.0^{\circ} \mathrm{C}$ compared with the other zone segments. The segment is located in the bottom of the core directly connected with the fuel discharge channel. The EPR basic design has also calculated the thermal hydraulic characteristics in the core and resulted in the maximum pebble temperature of $1,015{ }^{\circ} \mathrm{C}$. That comparison value is lower than the preliminary calculation because heat losses have been considered, in which the heat in the helium coolant is also transferred through the reactor pressure vessel and the air gap to the reactor cavity cooling system (RCCS). By design, the RCCS in the EPR contains three trains of cavity pipe, evaporation tank, and smaller cooling tower [15], which operates under normal operating condition. The above simulation was conducted under steady-state condition, which is showed by the steadystate core outlet temperature reaching the value of $693.87{ }^{\circ} \mathrm{C}$ from the core inlet temperature of $243.07{ }^{\circ} \mathrm{C}$ with the absorbed heat by the helium coolant approaching $9.99 \mathrm{MWt}$. By design, the EPR core operated under $10 \mathrm{MWt}$ power should increase the helium temperature of $243{ }^{\circ} \mathrm{C}$ to 700 ${ }^{\circ} \mathrm{C}$. In general, the calculated core temperature distribution is still preliminary and requires further researches by considering other factors such as more representative radial and axial power distribution, decrease of core mass flow of about $87 \%$, and heat loss to the reactor pressure vessel.

\section{CONCLUSION}

Preliminary results of EPR core temperature distribution have been obtained by developing the model in the EPR core section. The EPR core section consisting of the pebble bed, outlet channels, and hot gas plenum have been modelled using RELAP5/SCDAP/Mod3.4 to be simulated with $10 \mathrm{MWt}$. It shows that the core temperature distribution under assumed model of 4 core zones is below the limiting pebble temperature of $1,620^{\circ} \mathrm{C}$ with the highest pebble temperature of $1,477.0$ ${ }^{\circ} \mathrm{C}$. The results are still preliminary but representative enough to describe the core safety of the EPR design to be included in the EPR detail design document as necessary. Further researches are required by considering other factors such as more representative radial and axial power distribution, decrease of core mass flow, and heat loss to the reactor pressure vessel. 


\section{ACKNOWLEDGEMENT}

This work was jointly funded by BATAN research budget (DIPA) and RISTEKDIKTI research project (INSINAS) of the year 2018, which is being managed by Center for Nuclear Reactor Technology and Safety (PTKRN). The author is very thanksful to all staffs of Reactor Safety Technology Division for their valuable supports in developing the RELAP5 model.

\section{REFERENCES}

1. Kadak A. C. The Status of the US High-temperature Gas Reactors, Enginnering 2016; 2: $119-123$.

2. Zhou X.W., Tang Y. P., Lu Z. M., Zhang J., Liu B. Nuclear graphite for high temperature gas-cooled reactors, Carbon 2017; 124: $725-727$.

3. Kadak A. C. A future for nuclear energy: pebble bed reactors, Int. J. Critical Infrastructures 2005; 1 (4): $330-345$.

4. Setiadipura T., Bakhri S., Sunaryo G.R., Wisnubroto D.S. Cooling passive safety features of reaktor daya eksperimental. In: International Conference on Thermal Science and Technology (ICTST), AIP Conf. Proc. 2018; 1984020034.

5. Zhang Z., Dong Y., Li F., Zhang Z., Wang H., Huang X., Li H., Liu B., Wu X., Wang H., Diao X., Zhang H., Wang J. The Shandong Shidao Bay 200 MWe high-temperature gascooled reactor pebble-bed module (HTR-PM) demonstration power plant: an engineering and technological innovation, Engineering 2016; 2: 112-118.

6. Scari M. E., Costa A. L, Pereira C., Velasquez C. E., Veloso M. A. F. HTR steady state and transient thermal analyses, Int. J. Hyd. Energy 2016; 41: $7192-7196$.

7. Lee W. J., Jeong J. J., Lee S. W., Chang J. H. Development of MARS-GCR/V1 for thermal-hydraulic safety analysis of gas cooled reactor systems, Nucl. Eng. Tech. 2005; 37 (6): $587-594$.

8. Ekariansyah A. S., Widodo S. Benchmarking of experimental setup for pressure drop calculation in a packed pebble bed using RELAP5, presented in: Symposium of Emerging Nuclear Technology and Engineering Novelty (SENTEN 2018), Palembang, July 4 - 5, 2018.

9. Badan Tenaga Nuklir Nasional, Preparation of Preliminary Engineering Design Document for Experimental Power Reactor (RDE) - Optional Report Conceptual Design Reactor Core, Document No. RDE/DS-WBS02-201-004, 12 December 2015.

10. International Atomic Energy Agency, Evaluation of High Temperature Gas Cooled Reactor Performance: Benchmark Analysis Related to the PBMR-400, PBMM, GT-MHR, HTR-10 and the ASTRA Critical Facility, IAEA-TECDOC-1694, Vienna, 2013.

11. Abdulmohsin R. S., Al Dahhan M. H. Pressure drop and fluid flow characteristics in a packed pebble bed reactor, Nucl. Tech. 2017; 00: 1-9.

12. Setiadipura T., Irwanto D., Zuhair. Preliminary neutronic design of high burnup OTTO cycle pebble bed reactor, Atom Indonesia 2015; 41 (1): 7 - 15.

13. Seeger O., Laurie M., El Abjani A., Ejton J., Boudaud D., Freis D., Carbol P., Rondinella V.V., Futterer M., Allelein H. J. KuFA safety testing of HTR fuel pebbles irradiated in the high flux reactor in Petten, Nucl. Eng. Des 2015; 306:59-68.

14. Zang Z., Wu Z., Sun Y., Li F. Design of the Chinese modular high-temperature gascooled reactor HTR-PM, Nucl. Eng. Des. 2006; 236:485 - 490.

15. Subekti M., Bakhri S., Sunaryo G. R. The simulator development for RDE reactor, In: International Conference on Nuclear Technologies and Sciences (ICoNETS 2017), IOP Conf. Series: J. Phys.: Conf. Ser. 2018; 962012054. 